Essay

\title{
From Shapeshifter to Lava Monster: Gender Stereotypes in Disney's Moana
}

\author{
Madeline Streiff ${ }^{1}$ and Lauren Dundes ${ }^{2, *}$ \\ 1 Hastings College of the Law, University of California, 200 McAllister St, San Francisco, CA 94102, USA; \\ madeline.streiff@uchastings.edu \\ 2 Department of Sociology, McDaniel College, 2 College Hill, Westminster, MD 21157, USA \\ * Correspondence: ldundes@mcdaniel.edu; Tel.: +1-410-530-6548
}

Received: 6 July 2017; Accepted: 4 August 2017; Published: 8 August 2017

\begin{abstract}
Moana (2016) continues a tradition of Disney princess movies that perpetuate gender stereotypes. The movie contains the usual Electral undercurrent, with Moana seeking to prove her independence to her overprotective father. Moana's partner in her adventures, Maui, is overtly hypermasculine, a trait epitomized by a phallic fishhook that is critical to his identity. Maui's struggles with shapeshifting also reflect male anxieties about performing masculinity. Maui violates the Mother Island, first by entering her cave and then by using his fishhook to rob her of her fertility. The repercussions of this act are the basis of the plot: the Mother Island abandons her form as a nurturing, youthful female (Te Fiti) focused on creation to become a vengeful lava monster (Te Kā). At the end, Moana successfully urges Te Kā to get in touch with her true self, a brave but simple act that is sufficient to bring back Te Fiti, a passive, smiling green goddess. The association of youthful, fertile females with good and witch-like infertile females with evil implies that women's worth and well-being are dependent upon their procreative function. Stereotypical gender tropes that also include female abuse of power and a narrow conception of masculinity merit analysis in order to further progress in recognizing and addressing patterns of gender hegemony in popular Disney films.
\end{abstract}

Keywords: hypermasculinity; phallic symbol; gender stereotypes; emasculation; male performance; shapeshifting; Electral; Maui; fishhook; princess

\section{Introduction}

The financial success of Disney's princess franchise has resulted in concerns about how its characters might influence audiences, particularly developing youth (Coyne et al. 2016; England et al. 2011; Do Rozario 2004). Aside from objections to the brevity of the directors' pre-production three-week visit to Polynesia (Varner 2016) and the ensuing syncretization of Polynesian cultures portrayed in Disney's Moana (Clements and Musker 2016; Diaz 2016a, 2016b), many critics praised Moana as a brave heroine with a sense of humor and a commitment to saving the world without romantic distractions (Dunsmore 2017; Duralde 2016; Machado 2016; Ngata 2016; To 2016). Furthermore, Moana differs from previous non-white Disney princesses subject to orientalization (Lacroix 2004).

Despite what is arguably progress in the princess genre due to Moana's adventurous spirit, the challenges she faces derive from a common coming-of-age plot: the need to prove to her overprotective father that she can be independent (playing to an Electral theme common in Disney features). Although academic critiques of Disney's princess films tend to explore the role of princess exemplars for girls (e.g., Coyne et al. 2016; Dundes and Streiff 2016), Disney's portrayal of manhood also merits analysis. Disney's Moana (2016) achieved substantial box office success, earning $\$ 643$ million worldwide by the end of April 2017 (Box Office Mojo 2017), in part due to having two protagonists: a female, Moana, and a male, Maui. Yet largely absent from discussions of the film to date are ways in which Moana's companion Maui perpetuates conventional phallocentricism, contributing to the "boy code" which 
promotes a mask of masculinity (Pollack 1999) that also encourages rigidity in gender performances and identities commonly found in Disney movies (Spencer 2014). Another principal character, the antagonist, Mother Island (a Mother Earth equivalent), also known both as Te Fiti and Te Kāar, raises concerns about portrayals of females; she wreaks destruction when angry, misusing her power, until Moana convinces her to get in touch with her "true" self.

In the end, the film relies on conventional tropes: Moana struggles to follow her dreams in defiance of her father and successfully calms the Mother Island; Maui faces insecurities as a man, a quest that may be relatable to young men who likewise are plumbing the depths of manhood in a society that rewards hypermasculinity (Mosher 1991), a continuation of Disney's influence on shaping norms of sexuality and body type (Griffin 2000). Resolution occurs when Moana is reunited with her father and Maui regains possession of his fishhook, while the Mother Island goes dormant. These elements of the plot explored in this paper support hegemonic masculinity that is associated with compromised health and well being (Courtenay 2000; Dundes and Dundes 2002; Juvrud and Rennels 2017; Pascoe and Bridges 2016).

The interpretation of Moana in this essay relies on content analysis to illustrate patterns of gender hegemony using a psychoanalytic perspective. The application of Freudian thought provides one possible reading of the gender patterns that are repeatedly employed in Disney movies, probably unconsciously, but in accordance with patriarchal hierarchy and hypermasculinity, as explored in the authors' prior analyses of Disney movies (e.g., Dundes and Streiff 2016; Streiff and Dundes 2017).

\section{Plot Summary}

The title character Moana works to repair the damage caused by the demigod Maui who steals the heart of the Mother Island goddess Te Fiti that possesses the power of creation. Maui is then confronted by the lava monster Te Kā (the alter ego of Te Fiti, the Mother Island). In the ensuing battle, he loses his magical fishhook that comes to be in the possession of Maui's rival, Tamatoa, an egotistical crab who displays it as a trophy.

The main story begins one thousand years later as Moana disobeys her protective father in order to find Maui who is marooned on an island. She convinces Maui to help her restore Te Fiti's heart in her quest to end a spreading blight. After facing a number of obstacles, including Moana's self-doubt and Maui's narcissism, the pair retrieve Maui's hook and find Te Kā who allows Moana to return her heart, whereupon she transforms back into Te Fiti, revitalizing the earth.

\section{Hypermasculinity}

\subsection{Physical Strength}

The movie begins by introducing viewers to the physically imposing, muscular Maui, voiced by former professional wrestler and body builder Dwayne Johnson, "Man of the Century" according to Muscle and Fitness as well as People's "Sexiest Man Alive" in 2016 (Jordan 2016), a departure from Maui's usual portrayal as a lithe teen on the cusp of maturity (Herman 2016). Johnson's notable height at $6^{\prime} 5^{\prime \prime}$, renowned musculature, and his moniker, "The Rock", all contribute to his cachet as a sex symbol. These traits are relevant to Maui's first "daring" (1:34) on-screen act, the violation of Te Fiti, the Mother Island, described with positive connotations as a feat of a "warrior" (1:49).

\subsection{Male Hero as Predatory}

To steal the "heart" of Te Fiti, Maui uses his magical fishhook to shapeshift, first transforming into his favorite non-human form as a hawk: a raptor (which connotes violence given its etymology from the Latin word rapere, meaning rape). Soon thereafter, he wriggles through a slit (1:53-55) to enter Te Fiti's dark cave (symbolic of a vagina (Somerville 1922)), and after returning to his human form, he uses his fishhook to pry out her "heart" which holds the power of creation and at times looks remarkably like an egg (see, e.g., 2:06-09; 3:12). Te Fiti's procreative "heart" inextricably links sex with 
love for women, contrasting with Maui's aggressive violation of Te Fiti's body. Disney's story is a twist on traditional lore in which Maui shapeshifts into a worm and then enters the toothed vagina of Hine-nui-te-pō. Maui's invasion prompts her to crush him with obsidian teeth lining her vagina, an object lesson discouraging rape (Craig 1989; Roheim 1940).

\subsection{Male Usurpation of Creation}

Maui's theft of the power of procreation builds on his earlier creation of "the islands [he] pulled from the sea" (39:44-47). Disney references mythical Maui's creation of the Hawaiian Islands after catching his hook on the ocean floor and tricking his brothers into paddling as hard as possible, supposedly to catch a big fish (Tregear 1891, p. 236). This form of earth diver male creation fantasy involving mud from the ocean floor (Dundes 1962) complements Disney's extension of this theme in which men usurp women's creative powers, setting the stage for a battle of the sexes (specifically Maui versus the Mother Island's form as Te Kā).

\section{Fishhook as Phallus}

\subsection{Symbolic Equivalent}

The fishhook is an essential part of Maui's character, prominently featured in promotional material, which included versions in which a huge fishhook appears to extend from his groin (see Teaser-Trailer.com (2016)) (perhaps a nod to Priapus, notably the patron god of fishermen who is often portrayed with a giant phallus). In order for Maui to feel equipped to battle the forces of evil, he needs his fishhook. Of note, the hook sparks with heat when in use (as with Triton's trident in The Little Mermaid (Dundes and Dundes 2000), lending weight to its role as a phallic symbol.

Because the fishhook is a symbol of masculinity, designed to penetrate the cave-like mouths of fish (possibly connected to the Greek word delphos, meaning both fish and womb (Marino 2010), the fishhook must be extracted from the clutches of a male rival, Tamatoa, a crab who prominently displays it on his back as a trophy. The crab claims to lust for shiny objects and possesses extensive golden adornments. However, the fishhook is not shiny since its association with masculinity apparently trumps other attributes of the crab's treasure trove.

Maui's fishhook is designed to catch fish, and thus is a form of fishing rod, a tool that is a known phallic symbol (Dundes 1997). Biblically (according to Numbers 17:8), a rod's ability to bear ripe almonds which are seeds (not nuts), is connected to the ancient Greco-Roman association of the juice of almonds with semen (Tresidder 2012). Maui's fishhook, made out of bone (connoting the term boner), allows him to shapeshift and is designed to impale his prey, making him a fisherman of sorts. Fishermen are known to brag about the size of the fish they catch and may have a trophy fish "mounted" and displayed in a man-cave (Dundes 1997). In fact, it is notable that the word fisherman itself defies a gender-neutral form. Even the more gender-neutral term for a person that sells fish, fishmonger, traditionally had a female form: fishwife. Gender coding in Moana is inconsistent with Polynesian culture in which names, including moana (meaning ocean), can be used for both males and females (such as in Robert Flaherty's 1926 movie filmed in Samoa in which the title character Moana is male).

The logic of the fishhook as a symbol of masculinity is clarified by its categorization as fishing tackle, given its etymology: "grasp, seize" (Online Etymology Dictionary 2017). In the sports arena, tackle is applicable to two male-dominated activities, football and fishing, connoting strength and domination. Maui's preferred state as a hawk, not coincidentally meaning a proponent of an aggressive or warlike policy, complements the fishhook and its ability to seize and impale prey. The impalement theme is also relevant to the name of Moana's exaggeratedly buff father, Chief Tui, as the word tui is a title for a tribal chief as well as a Samoan word for both injection and fork, an echo of the hypermasculine King Triton and his powerful trident in Disney's The Little Mermaid. 


\subsection{Fishhook as Paramount}

Although Maui shares adventures with Moana, specifically to return the heart of Te Fiti, Maui's unequivocal priority is to find and aptly wield his fishhook. When Moana and Maui fail in their first attempt to return the heart of Te Fiti, Moana tries to remain upbeat. In contrast, Maui is clearly very angry-but not because he has been hurt or failed to achieve his goal. He is irate after his fishhook has been cracked and is in danger of breaking, putting him at risk of symbolic castration (1:16:07). When Moana suggests fixing it, Maui emphatically roars, "We. Can't. FIX. It" (1:16:28-30). Because Maui's fishhook defines his masculinity, when Te Kā later emasculates Maui by breaking and rendering useless his fishhook (1:27:24), she becomes a more formidable villain.

Maui's attachment to the hook could reflect how it is portrayed as a body part rather than an external tool. When Maui shapeshifts into a hawk, the fishhook is indeed part of his body, contained within the underside of one of his wings. Perhaps most striking in the centrality of the fishhook to Maui's identity is his lament, repeated twice: "Without my hook, I am nothing" (1:16:52-56). Within this context, Maui's lack of relationship or even interest in any women makes sense as his virility is focused on obtaining and wielding his fishhook. The fact that Maui's alter ego tattoo, his superego Mini Maui, nearly always holds the hook reinforces its critical role in Maui's identity.

\subsection{Haka Dance in Absence of Fishhook}

In the brief period that Maui perseveres without his hook, he tries to intimidate Te Kā by engaging in a Maori warrior haka dance as a way to "perform masculinity" (Calbris 2011, p. 216). In fact, the haka dance, although traditional, nevertheless perpetuates hypermasculinity as "the archetypal performance of Polynesian warrior masculinity" which contrasts with the feminine hula dance (Tengan and Markham 2009, p. 2422) which Moana performs early in the film. The haka dance, however, is no substitute for the hook, which Maui claims is not central to his identity but which he nevertheless eagerly embraces when Te Fiti inexplicably forgives him and replaces it. Maui's ensuing elation is hardly an object lesson in how to treat women or evidence that Maui has moved past an obsession with his fishhook. As if to emphasize Maui's renewed masculinity once he is finally equipped with a new, fully functioning hook, a spurt of water shoots upward simultaneous with his transformation into a hawk (1:33:23), a reminder that male power resides in the hook.

\section{Shapeshifting}

\subsection{Shapeshifting as Metaphor for Male Performance}

Aside from possessing an enormous fishhook, shapeshifting is also connected to Maui's sense of power. His ability to control the hook is clearly linked to his masculinity, as it may subconsciously reflect male performance anxiety, specifically the ability to get an erection. The flaccid phallus can transform, or shapeshift, into an erection (a preoccupation possibly reflected in the term straight to denote heterosexuality (Dundes 2004)). It may be significant that in his honorific title: Maui, shapeshifter, demigod of the wind and sea-shapeshifter is mentioned first.

\subsection{Linguistic Links between Phalluses and Tails}

Maui's shapeshifting is controlled by his fishhook, with mythical origins in its resemblance to the scorpion tail constellation. Tail is etymologically linked to the word for penis, exemplified by the German word for both: schwanz. Similarly, in English, the word penis also originally meant tail, as they both hang from the body. Not only are the words tail and penis connected, but related idioms in various languages also convey the importance of an erection in self-worth. In American culture, having one's tail between the legs (meaning hurt pride or shame) is rooted in contempt for males who cannot "man up". The up or down position of a tail is also significant in Swedish (hög svansföring: high tail, proud; svansen mellan benen: tail between the legs (Håkansson 1989, p. 93)). Similarly, the Spanish insult pendejo, which can imply that a man has been "degraded sexually" (Gudeman 2013, p. 107), is 
likely linked to pender, meaning to hang or dangle. This pendulous state contrasts with the ability to achieve tumescence (akin to thumbs-up symbolism).

\subsection{Shapeshifting in Other Disney Movies}

In the so-called "Disney universe", shapeshifting is also mostly the province of males, such as the Beast from Beauty and the Beast. The Beast is a chimera, with the head and horns of a buffalo as well as other masculine traits. Pinocchio also qualifies as a shapeshifter, including his partial transformation into a donkey and his extensible nose. Although women shapeshift, those who do tend to be villains, as when Te Fiti transforms into Te Kā or in the case of the wicked stepmothers in Snow White and Sleeping Beauty, and Ursula (Little Mermaid) who becomes masculine when she shapeshifts (Dundes and Dundes 2000). In Sleeping Beauty, Maleficent shapeshifts, wears clothes with spikes and horns, and wields a staff consisting of a ball and a long rod, reminders that she is usurping male power, before she is re-feminized by Prince Philip's sword thrust.

In Disney's Aladdin (1992), the title character relies on the power of the Genie to shapeshift (Chinen 2016), a power so important that it is also sought by the villain Jafar. When the Genie transforms Aladdin into a prince, the Genie calls him muy macho, and even shapeshifts into Arnold Schwarzenegger, a former Mr. Universe, who like Dwayne Johnson was celebrated for his male physique. Just as Maui bemoans that he is "nothing without his hook" (1:16:52-56), Aladdin feels insecure without the shapeshifting Genie (who inflates when Aladdin rubs the lamp): "Without you, I'm just Aladdin" (Aladdin: 1:08:21), a fear reinforced by Jafar: "Without the Genie, boy, you're nothing" (Aladdin: 1:20:03-07, emphasis added).

The preoccupation with shapeshifting could reflect fears about control of the phallus, which at times seems like an alter ego; this pattern is evident in men who may even assign their phallus its own name (see Murphy 2001, p. 34). It is indeed telling that men "confess to having conversations with their penis, cajoling it, asking it to stay erect" (Badinter 1995, p. 137).

\section{Crab (Tamatoa) as a Foil for Maui's Masculinity}

The inclusion of the crab, Tamatoa, provides Maui with a beta male adversary whose defeat can enhance his masculinity, in accordance with the notion of comparative masculinity as a zero-sum game (Patterson and Spencer 2017). After entering the crab's lair, Maui incites the hidden crab to emerge after telling Moana that he previously had ripped off one of Tamatoa's legs, connoting symbolic castration. After Maui is finally reconnected with his fishhook (and kisses it), he taunts the crab with a feminizing greeting, "Hey Crabcake ... I'm back" (1:02:27-34). Despite his own physical prowess and size, Tamatoa fears Maui when the latter is equipped with his magical fishhook, until the crab learns it is not operational. When Maui has trouble shapeshifting, the crab accuses him of being small, with a string of belittling adjectives: "You little semi-demi-mini-god" (1:03:02-05), a prelude to measures of stereotypical manhood as the crab tells Maui, "You tried to be tough, but your armor's just not hard enough" (1:04:02-08). These insults of failed masculinity contrast with the crab's own hard shell, durable for battle: "Send your armies but they'll never be enough; my shell's too tough" (1:03:31-35). At one point, Tamatoa impales Maui's foot and drags him, a feminizing assault threatening to Maui's masculinity (1:03:36-39).

In a more overt taunt after Maui reveals his inability to wield his hook, the crab says, "What a terrible performance", a jibe that connotes impotence (as does the term impaired male performance). Building on the humiliation, Tamatoa follows with, "You don't swing it like you used to, man" (1:03:05), employing sexual innuendo, as the word swing can denote sexual activity. The meaning of the word impotence, "unable to achieve an erection" but, literally, powerless (Reynaud 1983, p. 64), reflects males' sexual performance as critical to their identity.

Although Tamatoa attempts to devour Maui, Maui successfully struggles to keep the crab from crushing him in his maw, in a pose reminiscent of a weightlifter straining to lift a heavy barbell. Of note, Maui's escape from the jaws of death (of Tamatoa) is a departure from Maui's aforementioned 
mythical death from the sharp, obsidian, barracuda-like teeth of goddess Hine-nui-te-pō's vagina dentata (Craig 1989). Tamatoa's teeth are all a non-castrating molar shape, contrasting with the canines hanging from Maui's necklace that he always wears, a detail that helps distinguish Maui as more masculine than his rival.

Much of the segment is a male-against-male battle (not surprising given that the fishhook is the prize); it is about male humiliation, as manifested at the end of the scene when Tamatoa is knocked on his back, stranded, by a phallic geyser blast (where he remains, feminized, pictured in an extra scene after the credits roll) (1:46:16-1:48:16). Although some viewers have deemed the inclusion of the crab to be gratuitous (Varner 2016), Tamatoa serves an important function by directly challenging Maui's masculinity in order to underscore the demigod's need to re-possess his hook.

This male-on-male battle scene downplays the role of the title character, starting with Maui initially using Moana as "bait" to draw out Tamatoa, underscoring her minimal role in Maui retrieving his fishhook (yet making use of fishing idioms with the word bait). Moana spends part of the battle in a cage, later exiting quite easily, driven by her maternal instincts and anger after the crab's cruel reminder that Maui's parents had abandoned him. She bests the crab without harming him physically (which would be unfeminine), by tricking him into allowing them to escape by flashing a bioluminescent barnacle resembling the heart of Te Fiti. Moana's limited role is relevant to the denigration of female warriors connected to the archaic meaning of virago, a word that originally meant female warrior but evolved into meaning a domineering, violent, or bad-tempered woman. Its archaic, neutral meaning of a woman of masculine strength or spirit (related to the Latin word for man, vir) developed negative connotations because powerful women are seen as usurping control that is most suitable for men. Given the persistence of gender roles, it is not surprising that Moana does not directly battle the crab, but rather works to resolve conflict in other scenes that involve the more stereotypical feminine realm of family dynamics, specifically her efforts to navigate her relationship with her father.

\section{Electral Theme}

Moana's identity is based on her connection to her father, Chief Tui, as she tells Maui: "I'm not a princess. I'm the daughter of the chief" (52:07-12). Like Ariel in the Little Mermaid, Moana has an overprotective father, who is vehemently opposed to her traveling beyond the reef. Although Chief Tui decrees that no one go beyond the reef, he seems most concerned that his daughter abide by the rule. Moana's rebellion and her father's adamancy in trying to keep her safe at home add an Electral element that pits a daughter's yen to explore against her father's unwillingness to allow his daughter to look for more "fish in the sea" (a theme of paternal control of sexuality also in Frozen (Streiff and Dundes 2017)). It is key that this restriction comes only from Moana's father; in fact, the mother does not have much of a role in the movie and acts more like a friend than an authority figure. When the mother catches Moana packing up to leave unauthorized, she gives Moana her blessing by handing her a bundle with fruit inside, tacitly sanctioning her voyage beyond the reef (30:58). Because Moana's rebellion is very clearly against her father, it seems likely that her quest to venture beyond the reef reflects paternal concern about a daughter's transition to sexual exploration.

This interpretation of fishing beyond the reef is supported by the expression "There are plenty of fish in the sea", meaning that there are many potential mates in the world. Moana's father's insistence on keeping her close, despite a compelling reason to fish further away, suggests that he wishes to protect her from suitors and guard against her potential vulnerability to men who fall out of his range of dominion where he wields some control as chief. Regardless of Moana's lack of romantic interests, her father's concerns reflect parental worries that emerge when children achieve maturity (a phase of development matching that of the Hawaiian actress Auli'i Cravalho, who voiced Moana beginning at the age of 14).

Chief Tui's hidden fleet of extra boats in an off-limits cave blocked with boulders provides a metaphor for these concerns. The chief has an unduly harsh response to his daughter's discovery of the boats in the cave that can take her away from the island and beyond his control. Like The Little 
Mermaid's Triton who is threatened by his daughter Ariel's infatuation with the statue of Prince Eric hidden in a cave, Chief Tui overreacts to Moana's discovery of the boats, and is distracted only by his own mother and her condition (the chief's father is not mentioned, consistent with an Oedipal pattern). Although her father wants her to be the next chief (recognized as counter to cultural realities (Varner 2016)) — he still carefully guards the entrance to the cave, a possible virginity metaphor.

Moana: This cave has boats ... Dad. What are you doing?

Chief Tui: I should've burned those boats a long time ago [he grabs a burning torch and heads off, presumably in the direction of the cave with the boats]

Moana: No! Don't! ...

Villager: Chief! It's your mother! (28:56-59)

The song title "How Far I'll Go" could serve as a double entendre in terms of Moana questioning whether she can be "the perfect daughter" as she feels drawn to "the place I know, where I cannot go, where I long to be ... " Although she wishes to be "satisfied" if she "play[s] along", she wonders if she will "cross that line" and how far she will go.

In her first attempt to venture beyond the reef, she almost drowns, but even after that traumatic event, she is most concerned about her father finding out that she plans to cross the line. This is familiar Disney territory, analogous to the Little Mermaid's defiance; the difference is that Moana wants to be the perfect daughter, and has a general yearning to explore which makes her sexually vulnerable as opposed to Ariel's fixation on Prince Eric. However, in both cases, the daughters' daring is a threat to only one person: their fathers, who wish to wield control over them. This theme of conflict in the transition from a father's control over sexuality to a child's independence likely resonates with viewers.

In both movies, the conclusion demonstrates the special bond between father and daughter. The last words in The Little Mermaid are, "I love you, Daddy", which Ariel whispers in her father's ear, while in Moana, we see her alone with just with her father in the concluding moments, as he guides a canoe. Her hand joins his momentarily on the rudder before she springs off to gallivant on the canoe, leaving control to her father. In other words, Moana is a voyager, but in the end, she pursues this interest in earnest with her father by her side; he's steering the canoe and clearly at the helm. Similarly, there is a harmonious ending with Pocahontas and her father, the chief, rather than with her new love interest, John Smith, underscoring the primacy of the Electral theme in another Disney movie. Moana's happy resolution at the end of the movie consists of proving to her father she is independent. In the film, we never see her tell her parents that she is responsible for ending the blight inflicted by Te Kā. The culminating moment is reuniting with her family, rather than telling them of her accomplishments.

\section{Women as Threatening}

After she is robbed of her power of creation, Te Kā is consumed by vengeful wrath described by Moana's grandmother as "draining the life from island after island until every one of us is devoured by the bloodthirsty jaws of inescapable death!" (3:33-46). This description of an angry female goddess as "draining life" and "bloodthirsty" is consistent with fears of the supposed liquid-sapping powers involved in evil eye attacks that are a threat to body fluids.

The word drain means to cause the water or other liquid in something to run out, leaving it empty or dry (Oxford Dictionarie 2017). Individuals cursed by the evil eye are thought to be at risk of desiccation, similar to how grapes shrivel into raisins, and related to beliefs surrounding the notion of a finite amount of a male's life force (semen) during intercourse (Dundes 1980). It is significant that Te Fiti has a youthful face when she is in her benevolent form, but as a lava monster associated with fire and heat, Te Kā fears and avoids water (hydration). In order for her to return to her former self and end her vengeance, she needs to shed her desiccated outer layer, which is associated with being old and dry, contrasting with rejuvenating liquid (e.g., the magically rehydrating Fountain of Youth (Dundes 1998)). 


\section{Witches and Fertility}

The "jaws of death" the grandmother mentions connote a vagina dentata, supported by the word labia (lips in Latin), which threaten men's masculinity through castration (Elwin 1943; Otero 1996), the fate of the mythical Maui mentioned above (although not portrayed in the Disney version). Castration fears are also reflected in the original conception of Te Kā as a wizened old "lava witch" (see (Trumbore 2016) for Te Kā's original rendering as a witch), notable since, historically, women seen as threatening have been denounced as castrating witches (complete with broomsticks they straddle to fly) (Smith 2002; Sollee 2017).

With her "heart" (fertility) restored, Te Kā transforms into Te Fiti while in the water. It is a type of rebirth that is a reminder that life begins with a flood of amniotic fluid, likely connected to the prevalence of flood myths around the globe (Dundes 1988). In addition, "the flood symbolizes the destruction of evil and allows the world to begin again; a rebirth of goodness is a result" (Stokowski 2009, p. 30). The destruction of evil (Te Kā), the lava monster, was necessary because Te Fiti was completely undone by the theft of her egg, making fertility central to the female identity (hence why she is referred to as the mother island). The terrain becomes lush once again, and there is rapid re-birth and re-growth. Her return as the Mother Island/Te Fiti-Moana's most significant achievement-restores a powerful woman to a prescribed female role: a nurturing, life-giving role. If deprived of the ability to give life, however, women are demonized as dangerous and spiteful. This explains why female witches and monsters are often both old and barren: "Woman becomes dangerous, monstrous, when the patriarchal desire to harness her sexuality and reproductive powers is denied resulting in the marginalization of the infertile woman as both physically monstrous and threatening to the status quo" (Santos 2017, p. 91). This theme of barren, castrating witches extends to one of the best-known witches, the Wicked Witch of the West (in the Wizard of Oz), who was so dry that she dissolved upon contact with water.

\section{Te Kā as a Lackluster Adversary Needing Pep Talk}

Once Te Kā sheds her crusty, dry exterior thanks to Moana, she resumes her identity as Te Fiti. The conclusion of the movie does not require a culminating battle with the decisive defeat of the chief antagonist. In fact, heroines cannot humiliate a male character, no matter how villainous, without being seen as castrating and unfeminine. Instead, Moana reasons with the lava monster Te Kā in order to convince her to return to her very feminine, maternal, flowery state as Te Fiti. Moana's act involves bravery in approaching Te Kā, but not any particular cleverness.

It is significant that even after suffering the loss of her procreativity, only calm reasoning is needed to remind Te Kā who she truly is, an astonishingly simple resolution of her rage after being violated and deprived of her procreativity as the Mother Island. Moana tames Te Kã with just a few reassuring words about remembering her true self, along with pressing her forehead and nose against the huge forehead of Te Kā, a traditional Maori greeting called a hongi in which the ha or breath of life is exchanged and intermingled (Ngata 2016). Including an element of Polynesian culture in the conclusion does not change the impression that Te Kā had a temper tantrum that just required rationality and equanimity to resolve. This anticlimactic resolution could result from the writers' relatively late decision to reduce Maui's role at the end in order in order to bolster Moana's importance in the eponymous film (Flaherty 2016).

The Te Fiti/Te Kã character possesses stereotypical positive and negative traits, which speak to perceptions of women as sweet and kind until overwhelmed by fury when provoked. While perhaps viewers can understand why the initial assault was worthy of anger, ultimately the vengeful reaction of hurting innocent people and the destruction of botanical life is not flattering to women. Indeed, Te Fiti reacted to the assault by becoming the lava-encrusted Te Kā, an incarnation incapable of verbally expressing herself. While in this altered state, she does not attempt to retrieve the heart herself, but rather remains infuriated and vengeful, a portrayal that conforms to notions of women as passive yet temperamental. 


\section{Conclusions}

Despite the promise of a new, ostensibly modern Disney princess, Moana reinforces gender stereotypes, perpetuating patterns found in other Disney princess films (Coyne et al. 2016; England et al. 2011; Dundes and Streiff 2016; Streiff and Dundes 2017). As the movie ends, Moana has ventured beyond the reef and explores the open seas, but under the tutelage of her father who now approves of her, a simplified Electral finish without complications of a love interest. Moana has ensured the return of the Earth's fertility, an archetypal female concern, while Maui rejoices in his newly restored fishhook, a principal focus that is a key symbol of his masculinity. These portrayals reveal Disney's continuing use of one-dimensional characters that can result in non-reflective viewing (Zipes 1995).

Moana returns to stereotypical tropes of masculinity and femininity, demonstrating Disney's tendency to imply that mighty females abuse power, in this case Te Kā, Te Fiti's alter ego, whose vengeance has caused devastating blight. In a parallel of the virgin or vamp dichotomy, the body of the character's benevolent form, Te Fiti, fades into the earth in a sleeping position, connoting dormancy and a willing, if temporary, relinquishment of her power and control. As with Elsa in Frozen, when angry, Te Fiti becomes a monster, specifically Te Kā, the lava monster, complete with a primordial reptilian-like gait as she surges towards Moana in the creature's final moments before returning to her form as Te Fiti. She is reminiscent of an angry Maleficent turned fire-breathing dragon in Sleeping Beauty. The implication is that females' humanity continues to be characterized by passivity while activity, namely wielding power, is linked to monstrosity.

In an echo of the conflict linked to Elsa's frozen heart in Moana's predecessor in Frozen, Maui's theft of Te Fiti's "heart" similarly wreaks havoc. Since according to portrayals by Disney, women seem to be driven by their hearts and not their heads, their aberrant or stolen hearts severely impair them. Audiences see powerful female characters who are ultimately good but whose perceived lack of emotional control devastates society. "Out-of-control" women need to conform to comportment modeled by gentle, loving, nurturing, reformed Te Fiti who returns to procreativity but shuns aggression and maintains her muteness which limits her literal and metaphorical voice and reinforces the patriarchal hierarchy.

Yet while women think with their hearts, men such as Maui think with their fishhooks, a gender gulf seemingly necessary for equilibrium. In Moana, the pat "happy ending" consists of the return of Te Fiti's heart (procreativity) and the reuniting of Maui with his fishhook (manhood). As a result, there is now order in the world because each sex regains what is arguably their sole driving and sustaining force. These themes connote an unspoken gender yin and yang that suggest a sense of resolution consistent with long-standing gender norms.

Female characters' heroism is confined by stereotypically feminine behavior that rarely includes conquering evil villains. Moana builds Maui's confidence, calms and reassures Te Kā and outwits but does not vanquish Tamatoa. As a feminine heroine, she cannot humiliate a male opponent, which is the province of male heroes seeking to boost their masculinity. In Maui's case, repossession of his fishhook and shapeshifting skills suffice as a victory, reinforcing a narrow and fraught conception of masculinity.

Acknowledgments: We would like to acknowledge the helpful suggestions of the reviewers.

Author Contributions: The authors contributed equally to researching and writing the essay.

Conflicts of Interest: The authors declare no conflict of interest.

\section{References}

Aladdin. 1992. Directed by Ron Clements, and John Musker. Produced by Ron Clements and John Musker. Screenplay by Ron Clements, John Musker, Ted Elliott and Terry Rossio; Burbank: Walt Disney Pictures.

Badinter, Elisabeth. 1995. On Masculine Identity. New York: Columbia University Press.

Box Office Mojo. 2017. Moana. Available online: http:/ / www.boxofficemojo.com/movies/?id=disney1116.htm (accessed on 24 April 2017). 
Calbris, Geneviève. 2011. Elements of Meaning in Gesture. Amsterdam: John Benjamins Publishing.

Chinen, Nate. 2016. Consider the Coconut: How Moana uses Polynesian culture to create a prototypical Disney story. November 22. Available online: http://www.slate.com/articles/arts/culturebox/2016/11/how_ moana_uses_polynesian_myths_to_create_a_disney_story.html (accessed on 16 May 2017).

Craig, Robert D. 1989. Dictionary of Polynesian Mythology. New York: Greenwood Publishing Group.

Courtenay, Will H. 2000. Constructions of Masculinity and Their Influence on Men's Well-Being: A Theory of Gender and Health. Social Science and Medicine 50: 1385-401. [CrossRef]

Coyne, Sarah M., Jennifer Ruh Linder, Eric E. Rasmussen, David A. Nelson, and Victoria Birkbeck. 2016. Pretty as a Princess: Longitudinal Effects of Engagement with Disney Princesses on Gender Stereotypes, Body Esteem, and Prosocial Behavior in Children. Child Development 87: 1909-25. [CrossRef] [PubMed]

Diaz, Vicente M. 2016a. Disney Craps a Cute Grass Skirt. September 29. Available online: http:// hawaiiindependent.net/story/disney-craps-cute-grass-skirt (accessed on 1 April 2016).

Diaz, Vicente M. 2016b. Don't Swallow (or be Swallowed by) Disney's 'Culturally Authenticated Moana'. Indian Country Media Network, November 13. Available online: https://indiancountrymedianetwork.com/ news/opinions / dont-swallow-or-be-swallowed-by-disneys-culturally-authenticated-moana/ (accessed on 1 April 2016).

Dundes, Alan. 1962. Earth-Diver: Creation of the Mythopoeic Male. American Anthropologist 64: $1032-51$. [CrossRef]

Dundes, Alan. 1980. Wet and Dry, the Evil Eye. In Interpreting Folklore. Bloomington: Indiana University Press, pp. 93-133.

Dundes, Alan. 1988. The Flood Myth. Berkeley: University of California Press.

Dundes, Alan. 1997. Traditional Male Combat: From Game to War. In From Game to War and Other Psychoanalytic Essays on Folklore. Lexington: University of Kentucky Press, pp. 25-45.

Dundes, Alan. 1998. The Vampire as Bloodthirsty Revenant: A Psychoanalytic Post-Mortem. In The Vampire. Madison: University of Wisconsin Press, pp. 159-79.

Dundes, Alan, and Lauren Dundes. 2002. The Elephant Walk and Other Amazing Hazing: Male Fraternity Initiation through Infantilization and Feminization. In Bloody Mary in the Mirror: Essays in Psychoanalytic Folkloristics. Jackson: University Press of Mississippi, pp. 95-121.

Dundes, Alan. 2004. As the Crow Flies: A Straightforward Study of Lineal Worldview in American Folk Speech. In What Goes Around Comes Around: The Circulation of Proverbs in Contemporary Life. Edited by Kimberly J. Lau, Peter Tokofsky, Stephen D. Winick and Wolfgang Mieder. Logan: Utah State University Press, pp. 172-87.

Dundes, Lauren, and Alan Dundes. 2000. The Trident and the Fork: Disney's 'The Little Mermaid' as a Male Construction of an Electral Fantasy. Psychoanalytic Studies 2: 117-30. [CrossRef]

Dundes, Lauren, and Madeline Streiff. 2016. Reel Royal Diversity? The Glass Ceiling in Disney's Mulan and Princess and the Frog. Societies 6: 35. [CrossRef]

Dunsmore, Carrie. 2017. Disney's Moana is a princess head and shoulders (and feet) above the rest. Washington Post. February 11. Available online: http:/ / www.stuff.co.nz/entertainment/ film/89307557/disneys-moanais-a-princess-head-and-shoulders-and-feet-above-the-rest (accessed on 5 May 2017).

Duralde, Alonso. 2016. Dwayne Johnson Invigorates Disney's South Seas Saga. The Wrap. November 23. Available online: https: / / www.thewrap.com/moana-review-dwayne-johnson-invigorates-disneys-south-seas-saga/ (accessed on 3 May 2017).

England, Dawn Elizabeth, Lara Descartes, and Melissa A. Collier-Meek. 2011. Gender Role Portrayal and the Disney Princesses. Sex Roles 64: 555-67. [CrossRef]

Elwin, Verrier. 1943. The Vagina Dentata Legend. British Journal of Medical Psychology 19: 439-53. [CrossRef]

Flaherty, Keely. 2016. Moana Almost Had a Very Different Ending. BuzzFeed, November 25. Available online: https: / www.buzzfeed.com/keelyflaherty/moana-is-the-disney-princess-we-all-need-right-now? utm_term=.oy8NB94v0\#.cnya29mlE (accessed on 1 June 2017).

Griffin, Sean. 2000. Tinker Belles and Evil Queens: The Walt Disney Company from the Inside Out. New York: NYU Press.

Gudeman, Stephen. 2013. Relationships, Residence and the Individual: A Rural Panamanian Community. New York: Routledge.

Håkansson, Gisela. 1989. Bodily Behaviour in Emotive Expressions. Working Papers; Lund, Sweden: Department of Linguistics, Lund University, vol. 35, pp. 89-98. 
Herman, Doug. 2016. How the Story of Moana and Maui Holds Up Against Cultural Truths. Smithsonian.com, December 2. Available online: http://www.smithsonianmag.com/smithsonian-institution/how-storymoana-and-maui-holds-against-cultural-truths-180961258/ (accessed on 16 May 2017).

Jordan, Julie. 2016. Dwayne ‘The Rock' Johnson Is This Year's Sexiest Man Alive! November 15. Available online: http:/ / people.com/celebrity/sexiest-man-alive-2016-dwayne-johnson-the-rock/ (accessed on 25 April 2017).

Juvrud, Joshua, and Jennifer L. Rennels. 2017. 'I Don't Need Help': Gender Differences in How Gender Stereotypes Predict Help-Seeking. Sex Roles 76: 27-39. [CrossRef]

Lacroix, Celeste. 2004. Images of animated others: The Orientalization of Disney's Cartoon Heroines from The Little Mermaid to The Hunchback of Notre Dame. Popular Communication 2: 213-29. [CrossRef]

Machado, Yolanda. 2016. Moana Directors Reveal How They Made Disney's Next Hit. November 23. Available online: https:/ / www.moviefone.com/2016/11/23/moana-directors-reveal-how-they-made-disneys-next-hit/ (accessed on 15 April 2017).

Marino, Katherine R. 2010. Setting the Womb in Its Place: Toward a Contextual Archaeology of Graeco-Egyptian Uterine Amulets by Brown Dissertation. Available online: https: / repository.library.brown.edu/studio/ item/bdr:11094/PDF/ (accessed on 2 May 2017).

Moana. 2016. Directed by Ron Clements, and John Musker. Produced by Osnat Shurer. Screenplay by Jared Bush. Story by Ron Clements, John Musker, Chris Williams, Don Hall, Pamela Ribon, Aaron Kandell and Jordan Kandell; Burbank: Walt Disney Pictures.

Mosher, Donald L. 1991. Macho Men, Machismo, and Sexuality. Annual Review of Sex Research 2: 199-247.

Murphy, Peter F. 2001. Studs, Tools, and the Family Jewels: Metaphors Men Live By. Madison: University of Wisconsin Press.

Ngata, Tina. 2016. Despite Claims of Authenticity, Disney's Moana Still Offensive. Rising up with Sonali, November 23. Available online: http://www.risingupwithsonali.com/despite-claims-of-authenticitydisneys-moana-still-offensive/ (accessed on 10 April 2017).

Online Etymology Dictionary. 2017. Available online: http://www.etymonline.com/index.php?term=tackle (accessed on 13 June 2017).

Otero, Solimar. 1996. 'Fearing our mothers': An Overview of the Psychoanalytic Theories Concerning the Vagina Dentata Motif F547.1.1. American Journal of Psychoanalysis 56: 269-88. [CrossRef] [PubMed]

Oxford Dictionaries. 2017. Available online: https:/ / en.oxforddictionaries.com/definition/drain (accessed on 13 April 2017).

Pascoe, Cheri Jo, and Tristan Bridges. 2016. Exploring Masculinities: Identity, Inequality, Continuity, and Change. Oxford: Oxford University Press.

Patterson, G., and Leland G. Spencer. 2017. What's So Funny about a Snowman in a Tiara? Exploring Gender Identity and Gender Nonconformity in Children's Animated Films. Queer Studies in Media E Popular Culture 2: 73-93.

Pollack, William. 1999. Real Boys: Rescuing Our Sons from the Myths of Boyhood. New York: Holt Paperbacks. Reynaud, Emmanuel. 1983. Holy Virility: The Social Construction of Masculinity. London: Pluto.

Roheim, Geza. 1940. The Garden of Eden. The Psychoanalytic Review 27: 1913-57.

Do Rozario, Rebecca-Anne C. 2004. The Princess and the Magic Kingdom: Beyond Nostalgia, the Function of a Disney Princess. Women's Studies in Communication 27: 34-59.

Santos, Cristina. 2017. Unbecoming Female Monsters: Witches, Vampires, and Virgins. Lanham: Lexington Books.

Smith, Moira. 2002. The Flying Phallus and the Laughing Inquisitor: Penis Theft in the 'Malleus Maleficarum' Journal of Folklore Research 39: 85-117.

Sollee, Kristen J. 2017. Witches, Sluts, Feminists: Conjuring the Sex Positive. Albany: Stone Bridge Press, Inc. Somerville, Henry. 1922. Practical Psycho-Analysis: An Introductory Handbook. Ann Arbor: University of Michigan Press.

Spencer, Leland G. 2014. Performing Transgender Identity in The Little Mermaid: From Andersen to Disney. Communication Studies 65: 112-27. [CrossRef]

Streiff, Madeline, and Lauren Dundes. 2017. Frozen in Time: How Disney Gender-Stereotypes Its Most Powerful Princess. Social Sciences 6: 38. [CrossRef]

Stokowski, Patricia. 2009. Symbolic Aspects of Water (Chapter 2). In Water and People: Challenges at the Interface of Symbolic and Utilitarian Values. Edited by Stephen F. McCool. Collingdale: Diane Publishing, pp. 19-59.

Teaser-Trailer.com. 2016. Available online: https:/ teaser-trailer.com/movie/moana/ (accessed on 15 January 2017).

Tengan, Ty P. Kāwika, and Jesse Makani Markham. 2009. Performing Polynesian Masculinities in American Football: From 'Rainbows to Warriors'. The International Journal of the History of Sport 26: 2412-31. [CrossRef] 
To, Benjamin. 2016. Dance, Storytelling and the Art of Wayfinding: Behind the Scenes of Disney's Moana. NBC News. Available online: http://www.nbcnews.com/news/asian-america/dance-storytelling-artwayfinding-behind-scenes-disney-s-moana-n672141 (accessed on 30 May 2017).

Tregear, Edward R. 1891. Maori-Polynesian Comparative Dictionary. Wellington: Lyon and Blair.

Tresidder, Jack. 2012. The Watkins Dictionary of Symbols. London: Watkins Media Limited.

Trumbore, Dave. 2016. 'Moana': Colorful Characters Revealed in New Images from Disney's Animated Epic. July 25. Available online: http://collider.com/moana-cast-characters-images / (accessed on 30 April 2017).

Varner, Will. 2016. Some Things about Disney's “Moana” That Real Polynesians Want You to Know. BuzzFeed, December 10. Available online: https://www.buzzfeed.com/willvarner/we-asked-polynesian-peoplewhat-they-thought-of-disneys-moan?utm_term=.ywdE34NO0\#.sa8oqz17P (accessed on 2 April 2017).

Zipes, Jack. 1995. Breaking the Disney Spell. In Mouse to Mermaid: The Politics of Film, Gender, and Culture. Edited by Elizabeth Bell, Lynda Haas and Laura Sells. Bloomington: Indiana University Press, pp. 21-42.

(C) 2017 by the authors. Licensee MDPI, Basel, Switzerland. This article is an open access article distributed under the terms and conditions of the Creative Commons Attribution (CC BY) license (http:/ / creativecommons.org/licenses/by/4.0/). 